Демічковська М.П., к. т. н., доч.

Київський національний торговельно-економічний університет, м. Київ, Україна Google Scholar https://scholar.google.com.ua/citations?user=CTOv7v0AAAAJ\&hl=ru

\title{
ТЕХНОЛОГІЯ ХЛІБОБУЛОЧНИХ ВИРОБІВ ПІДВИЩЕНОЇ ПОЖИВНОЇ ЦНННОСТІ
}

В останні роки спостерігається потреба зниження рівня споживання пшеничного борошна та підвищення біологічної цінності хлібобулочних та борошняних виробів для покращення здоров'я людини із використанням альтернативних видів борошна: житнього, гречаного, рисового, мигдального тощо [1].

Борошно вищого гатунку, яке $\epsilon$ основним складником, на думку дієтологів спричиняє захворювання шлунково-кишкового тракту, розвиток діабету та ожиріння. Основними складовими класичної рецептури лаваша $\epsilon$ борошно пшеничне вищого гатунку, закваска, вода та сіль. Тому актуальним $є$ розроблення технології лавашу 3 використанням борошна 3 кіноа та борошна з насіння чіа.

Одним $з$ найпопулярніших на сьогодні замінників пшеничного борошна є борошно з плодів кіноа, найкориснішого зі злаків. Перш за все, користь борошна 3 кіноа для здоров'я людини обумовлена багатим хімічним складом: великим вмістом білків (в сирих плодах кіноа 16,2\% білка, а в деяких сортах більше 20\%), харчових волокон, вітамінів групи А, В, Е, С, а також мінеральних речовин калію (172 мг/ 100 г), магнію (64 мг/ 100 г), заліза (1,49 мг / 100 г), кальцію (17 мг/ 100 г), цинку (1,09мг/ 100 г). Борошно з кіноа багате на лізин амінокислоту, яка допомагає засвоювати кальцій і сприяє швидкому загоєнню тканин [2].

Відомим нетрадиційним видом сировини, яка використовується у технології хлібобулочних виробів - це насіння чіа (борошно 3 насіння чіа). До його складу входить: білок - 20\%, поліненасичені жирні кислоти 34\% і клітковина - 25\%, антиоксиданти, вітаміни групи В, аскорбінова кислота, вітаміни РР, А (каротин), К; мінеральні речовини (кальцій, фосфор, магній, залізо, натрій, селен, мідь, калій, 
цинк, марганець). В насіннях чіа калію більше, ніж в бананах, заліза, ніж у шпинаті, кальцію, ніж у молоці [3].

При створенні модельних тістових композицій лаваша 3 використанням борошна з кіноа та борошно з насіння чіа враховували органолептичні характеристики вихідної сировини. 3 борошна 3 світлих сортів кіноа та борошно з насіння чіа випікають борошняні вироби, які виходять не тільки надзвичайно ароматним i дуже смачними, і корисними, але вони мають специфічні світло коричневе забарвлення.

Контролем слугував лаваш «Вірменський» виготовлений за традиційною технологією. Борошно з кіноа та борошно 3 насіння чіа має незвичайний горіховий смак і колір від білого до темно коричневого. Встановлено, що при додаванні 30\% борошна з кіноа та борошна 3 насіння чіа спостерігається покращення показників органолептичної оцінки лаваша «Оздоровчий» (5,0 балів). Це пояснюється м'яким приємним горіховим ароматом, притаманним борошну 3 кіноа та борошну 3 насіння чіа, та незвичним смаком $\mathrm{i}$ пористою, пухкою консистенцією готового хлібобулочного виробу. За результатами органолептичної оцінки визначено раціональне співвідношення борошна пшеничного вищого гатунку, борошна 3 кіноа та борошна 3 насіння чіа в технології лаваша «Оздоровчий» еквівалентне 70:30.

В результаті порівняння хімічного складу контрольного та дослідного зразків встановлено, що харчова цінність лаваша «Оздоровчий» перевищує контрольний зразок за такими показниками: вміст білків на $11,13 \%$, харчових волокон - на $36,86 \%$, вміст вітаміну А зріс у 15 разів, а вітаміну $\mathrm{B}_{2}$ у 2 рази, вітаміну $\mathrm{B}_{6}$ у 6 разів, вітаміну $\mathrm{B}_{9}$ у 24 рази, мінеральних речовин калію на 101,51 \%, цинку на $418,50 \%$, в той час як вміст крохмалю зменшився на майже $28 \%$.

Отже, розроблена технологія лавашу 3 додаванням борошна 3 кіноа та борошно 3 насіння чіа може бути рекомендована всім верствам населення України в межах фізіологічних норм замість їх традиційних аналогів.

\section{Список бібліографічних посилань}

1. Технологія продуктів харчування функціонального призначення монографія / А.А. Мазаракі, М.Ф. Кравченко, П.О. Карпенко [та ін.]; за ред. М.І. Пересічного. - 2-ге вид., переробл. та допов. К. : Київ. нац. торг.-екон. ун-т, 2012. - 1116 с. 
2. «КИНОА. Полезные свойства крупы. Как готовить киноа». Режим доступу: http://znaharka.com.ua/kinoa-poleznye-svojstva-krupy-kakgotovit-kinoa/

3. Насіння чіа: що це таке. - Режим доступу : http://osobista.in.ua/ nasinnya-chia-korysni-vlastyvosti-i-protypokazannya-skladzastosuvannya.html 